\title{
Solubility Enhancement of Oxcarbazepine by Melt Sonocrystallization Technique to Increase the Bioavailability
}

\author{
Vinayak Shivamurthy Mastiholimath ${ }^{1, *}$, Gauri Pradeep Mashelkar', Vinodkumar Shirshalappa \\ Mannur ${ }^{1}$, Panchaxari Mallappa Dandagi ${ }^{2}$, Pukar Khanal ${ }^{3}$
}

${ }^{1}$ Department of Pharmaceutical Quality Assurance, KLE College of Pharmacy, KLE Academy of Higher Education and Research (KAHER), Belagavi, Karnataka, INDIA.

2Department of Pharmaceutics, KLE College of Pharmacy, KLE Academy of Higher Education and Research (KAHER), Belagavi, Karnataka, INDIA.

${ }^{3}$ Department of Pharmacology, KLE College of Pharmacy, KLE Academy of Higher Education and Research (KAHER), Belagavi, Karnataka, INDIA.

\begin{abstract}
Objectives: The present study aimed to enhance the solubility of Oxcarbazepine by melt sono crystallization technique as well as increase its bioavailability. Materials and Methods: Tablets of Melt Sonocrystallized Oxcarbazepine were prepared by the direct compression method. Compression was performed on a Remik mini-press tablet compression machine using an $8 \mathrm{~mm}$ punch. The analytical method development was carried out in $20 \times 10$ and $10 \times 10$ twin trough chambers. The sample was spotted with a $100 \mu \mathrm{l}$ camas microliter syringe on silica gel aluminum plate $60 \mathrm{~F}_{254}(20 \times 10)$ and $(10 \times 10)$ plate; Merck using a CAMAG Linomat-5 sample applicator. Results: The Oxcarbazepine had better solubility in the ph 6.8 buffer. The mobile phase selected for HPTLC was Ethyl acetate: Methanol in the ratio $(8: 2 \mathrm{v} / \mathrm{v})$ with the $\mathrm{R}_{f}$ value 0.582 . The formulation $\mathrm{F} 2$ containing $5 \% \mathrm{SSG}$ showed a release of $90.51 \%$ and was considered as an optimized formulation based on several parameters such as friability $(0.21 \%)$, disintegration time $(27.8 \mathrm{sec})$ and in vitro dissolution studies.
\end{abstract}

Key words: Melt sonocrystallized, Oxcarbazepine, Method development, HPTLC, Validation, Solubility Enhancement.

\section{INTRODUCTION}

Epilepsy is defined as having two or more unprovoked seizures. Seizures are brief episodes of involuntary movement that may involve a part of the body (partial) or the entire body (generalized) and are sometimes accompanied by loss of consciousness and control of bowel or bladder function. Seizures are expected in adults with the age group of 60 and above. ${ }^{1}$ Oxcarbazepine is an antiepileptic drug generally used to treat generalized tonic-clonic seizures and partial seizures in humans. ${ }^{2}$ Oral bioavailability of Oxcarbazepine is $>95 \%$ and is not affected by food. By oral administration, Oxcarbazepine is completely absorbed and is converted into an active metabolite i.e. 10-monohydroxy metabolite (MHD).
The oral route of administration is the most convenient route of administration. The major problem faced during the oral administration of the active agent is the bioavailability factor, which ultimately depends on the solubility of the agent. Techniques for Solubility Enhancement include -Particle size reduction, Micronization, nanosuspension, Hydrotropy. ${ }^{3}$ Hot Melt Extrusion technique Steam aided granulation Floating granulation Sono crystallization Melt Sonocrystallization is a new particle design technology developed to modify the undesired properties of compounds such as poor flowability and solubility. ${ }^{4}$ This technique is an efficient tool to influence the external
Submission Date: 14-09-2020; Revision Date: 23-11-2020; Accepted Date: 08-02-2021

DOI: $10.5530 / \mathrm{ijper} .55 .1 \mathrm{~s} .37$ Correspondence: Dr. Vinayak Shivamurthy Mastiholimath

Professor, Department of Pharmaceutical Quality Assurance, KLE College of Pharmacy, Nehru Nagar, Belagavi-590010, Karnataka, INDIA.

Phone no: +919448527960 Email id: mastiholimath@ rediffmail.com

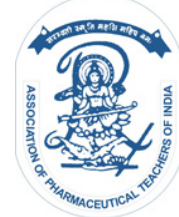

www.ijper.org 
appearance structure of crystalline products, smaller crystal size compared with conventional crystallization and cost-effectiveness of apparatus. Ultrasonication energy has been used to achieve nucleation at moderate super saturation during the crystallization process to achieve de agglomeration and to obtain the desired crystal habit. ${ }^{5}$ In the melt sonocrystallization technique the drug is first melted in the heavy liquid paraffin bath and the liquid drug is added to deionized water. Simultaneously subjected to sonication. The resultant solution is filtered and dried at room temperature. HighPerformance Thin Layer Chromatography is a powerful tool for qualitative and quantitative analytical tasks. ${ }^{6}$

\section{MATERIALS AND METHODS}

Oxcarbazepine was a gift sample from Vergo Pharma Research Laboratories Pvt. Ltd, Sodium Starch Glycolate, SLS, Talc, Magnesium stearate was procured from M/s Hi-Media Laboratories Pvt. Ltd, Microcrystalline Cellulose from M/s Ozone ${ }^{\circledR}$ International, Mumbai, Pregelatinized Starch from Colorcon Pvt. Ltd and PVP K-30 from M/s Balaji Drugs.

\section{Preformulation studies \\ Identification Tests \\ Melting point}

The melting point of Oxcarbazepine was determined by an open capillary method using theils tube apparatus.

\section{Lambda max $\left(\lambda_{\max }\right)$}

The $100 \mathrm{mg}$ of drug dissolved in $10 \mathrm{ml}$ of methanol in a $100 \mathrm{ml}$ volumetric flask and the volume was made up to $100 \mathrm{ml}$ with phosphate buffer $\mathrm{pH}$ 6.8. Further $10 \mathrm{ml}$ was pipette and diluted up to $100 \mathrm{ml}$ using phosphate buffer $\mathrm{pH} 6.8$ in a volumetric flask and the $\lambda_{\text {max }}$ was scanned in the range of $200-400 \mathrm{~nm}$ using a UV spectrophotometer

\section{FT-IR}

The FT-IR spectrum of Oxcarbazepine by potassium bromide method was carried out to confirm any changes in the purity of the drug.

\section{Standard Calibration Curve}

The primary stock solution of Oxcarbazepine was prepared by dissolving $100 \mathrm{mg}$ of a drug in $10 \mathrm{ml}$ of methanol in a $100 \mathrm{ml}$ volumetric flask and sonicated for $4 \mathrm{~min}$. The volume was made up to $100 \mathrm{ml}$ with $\mathrm{pH} 6.8$ buffer solution to get the concentration of $1000 \mu \mathrm{g} /$ $\mathrm{ml}$. From this, an aliquot of $10 \mathrm{ml}$ was withdrawn and it was diluted to $100 \mathrm{ml}$ with the buffer solution to give a concentration of $100 \mu \mathrm{g} / \mathrm{ml}$. Again from the above solution, aliquots of $0.5,1,1.5,2.0,2.5,3.0 \mathrm{ml}$ were pipette out into $10 \mathrm{ml}$ volumetric flask using phosphate buffer $\mathrm{pH} 6.8$ to get the concentrations of 5 to $30 \mu \mathrm{g} /$ $\mathrm{ml}$. The absorbance of this solution was measured at $\lambda_{\text {max }} 256 \mathrm{~nm}$ using a UV spectrophotometer.

\section{Method of Preparation of Melt Sonocrystallized ${ }^{7}$ Oxcarbazepine}

$1 \mathrm{~g}$ of Oxcarbazepine was melted in a test tube of $10 \mathrm{ml}$ capacity by placing it on a heavy liquid paraffin oil bath at a temperature of $215^{\circ} \mathrm{C}$. The molten mass was poured into deionized water maintained at a temperature of $50^{\circ} \mathrm{C}$. The suspension was sonocrystallized using a probe tip solicitor at a frequency of $33 \pm 3 \mathrm{kHz}$ and amplitude of $80 \%$ for 4 min with a cycle of $15 \mathrm{sec}$ ON and $15 \mathrm{sec}$ OFF. After sonication, the content is filtered off using Whatman filter paper no.1. The filtrate is dried at an ambient temperature of $60^{\circ} \mathrm{C}$ for several hours to obtain a dry mass. The percentage of practical yield was calculated.

\section{Solubility analysis}

To select the best solvent, solubility studies were carried out by preparing a saturated solution of a drug by adding an excess of a drug into different buffer solutions. The prepared solution was subjected to constant stirring for $24 \mathrm{hr}$. After this, the solution was filtered and analyzed spectrophotometrically at wavelength $256 \mathrm{~nm}$ with suitable dilutions.

\section{HPTLC method development}

The HPTLC is a widely used method of choice for the analysis of the substance. A CAMAG HPTLC was used for the estimation of Oxcarbazepine using the visioncats-software version 2.4.17207.2.

\section{Method Validation}

This includes the procedure of performing numerous assessments designed to verify that an analytical test system is suitable for its intended reason and is capable of providing beneficial and legitimate analytical data. The validation parameters included are Linearity, Limit of detection and limit of quantification, Precision, Specificity and Accuracy.

\section{Compatibility studies \\ Differential Scanning Calorimetry (DSC)}

Differential scanning calorimetry (DSC) analysis was performed on a DSC60 detector (Shimadzu Co., Japan). Approximately $4 \mathrm{mg}$ of melt sonocrystallized Oxcarbazepine along with excipients was weighed in an aluminum pan and sealed hermetically. DSC scan was recorded from $30^{\circ} \mathrm{C}$ to $300^{\circ} \mathrm{C}$ at a heating rate of $10^{\circ} \mathrm{C} /$ min under a nitrogen purge, using an empty pan as reference. 


\section{Formulation of Melt Sonocrystallized Oxcarbazepine tablet}

The $150 \mathrm{mg}$ of drug was taken and mixed with directly compressible diluents and super disintegrate in mortar. Magnesium stearate was passed through sieve no. 60, mixed and blended with the initial mixture in the mortar followed by compression of the blend. Compression was performed on a Remik mini-press tablet compression machine using an $8 \mathrm{~mm}$ punch by direct compression method (Table 1).

\section{Evaluation of tablets}

\section{The angle of Repose $(\theta)$}

The angle of repose is the maximum angle formed between the freestanding surface of the powder heap and the horizontal plane.

Angle of repose $(\theta)=\tan ^{-1}(\mathrm{~h} / \mathrm{r})$

\section{Bulk density and Tapped density}

The weighed amount of the sample is taken in a $25 \mathrm{ml}$ measuring cylinder and the volume of the packing is recorded and tapped until no change in the volume was noted on the hard wooden surface

$\begin{aligned} \text { LBD }(\text { Loose Bulk Density) } & =\frac{\text { Weight of powder }}{\text { Volume of packing }} \\ \text { TBD (Tapped bulk density) } & =\frac{\text { Weight of powder }}{\text { Tapped Volume of packing }}\end{aligned}$

\section{Compressibility Index and Hausner's Ratio}

Carr's Index $\%=\frac{\text { Tapped density }- \text { Bulk density }}{\text { Tapped density }}$ X 100

Hausner's Ratio $=\frac{\mathrm{Dt}}{D b}$

\section{Post compression parameters Drug Content Uniformity}

Random 5 tablets were crushed and powder equivalent to $150 \mathrm{mg}$ of the drug is dissolved in a minimum quantity of methanol in $100 \mathrm{ml}$ volumetric flask and the volume was made up to $100 \mathrm{ml}$ with a phosphate buffer of $\mathrm{pH}$
6.8. The resultant solution was filtered and $10 \mathrm{ml}$ of it was withdrawn in $100 \mathrm{ml}$ volumetric flask and volume was made with pH6.8 buffer solution and was analyzed spectrophotometrically at $256 \mathrm{~nm}$.

\section{In vitro Disintegration Time}

The in-vitro disintegration time of tablets was determined using the disintegration test apparatus as per I.P. specification using 6 tablets in phosphate buffer $\mathrm{pH} 6.8$ maintained at $37^{\circ} \mathrm{C} \pm 0.5^{\circ} \mathrm{C}$.

\section{In-vitro Dissolution Studies}

In vitro drug release of the formulation was carried out by the USP type II paddle apparatus with a rotating speed of $50 \mathrm{rpm}$ at a temperature of $37^{\circ} \mathrm{C} \pm 0.5^{\circ} \mathrm{C}$. The phosphate buffer of $\mathrm{pH} 6.8$ was used as a dissolution medium. $900 \mathrm{ml}$ of phosphate buffer was taken in the basket. The temperature was maintained at $37 \pm 0.50^{\circ} \mathrm{C}$ with a stirring speed of $50 \mathrm{rpm}$. Sink condition was maintained throughout the study by adding $5 \mathrm{ml}$ of phosphate buffer was every time after the withdrawal of aliquots. The samples withdrawn were filtered through Whatman filter paper no. 1 and assayed spectrophotometrically at $256 \mathrm{~nm}$.

\section{Short Term Stability Studies}

The purpose of stability studies is to determine how the quality of formulation varies with time under the influence of a variety of environmental factors such as temperature, humidity and light. Short term stability studies for the formulation F2 was performed at both room temperature and accelerated temperatures as per ICH guidelines. The tablets were analyzed on the $15^{\text {th }}$, $30^{\text {th }}, 45^{\text {th }}$ day it's for appearance, disintegration time, drug content and in vitro drug release.

\section{RESULTS AND DISCUSSION}

Melting point: The melting point of the drug was found to be between $215^{\circ} \mathrm{C}-219^{\circ} \mathrm{C}$. This indicates that the drug obtained was in pure form.

\begin{tabular}{|c|c|c|c|c|c|c|}
\hline \multicolumn{7}{|c|}{ Table 1: Formulation of Melt Sonocrystallized Oxcarbazepine tablet. } \\
\hline Formulation ingredients & F1 & F2 & F3 & F4 & F5 & F6 \\
\hline Msc oxcarbazepine & $\mathbf{1 5 0} \mathbf{~ m g}$ & $\mathbf{1 5 0} \mathbf{~ m g}$ & $\mathbf{1 5 0} \mathbf{~ m g}$ & $\mathbf{1 5 0} \mathbf{~ m g}$ & $\mathbf{1 5 0} \mathbf{~ m g}$ & $\mathbf{1 5 0} \mathbf{~ m g}$ \\
\hline Sodium Starch Glycolate & $3 \%$ & $5 \%$ & $7 \%$ & - & - & - \\
\hline Pre gelatinized starch & - & - & - & $3 \%$ & $5 \%$ & $7 \%$ \\
\hline Microcrystalline cellulose & $40.5 \mathrm{mg}$ & $37.5 \mathrm{mg}$ & $34.5 \mathrm{mg}$ & $40.5 \mathrm{mg}$ & $37.5 \mathrm{mg}$ & $34.5 \mathrm{mg}$ \\
\hline PVP K-30 & $1 \%$ & $1 \%$ & $1 \%$ & $1 \%$ & $1 \%$ & $1 \%$ \\
\hline SLS & $1 \%$ & $1 \%$ & $1 \%$ & $1 \%$ & $1 \%$ & $1 \%$ \\
\hline Magnesium stearate & $0.8 \%$ & $0.8 \%$ & $0.8 \%$ & $0.8 \%$ & $0.8 \%$ & $0.8 \%$ \\
\hline Talc & $0.5 \%$ & $0.5 \%$ & $0.5 \%$ & $0.5 \%$ & $0.5 \%$ & $0.5 \%$ \\
\hline
\end{tabular}


Lambda max $\left(\lambda_{\text {max }}\right)$ : The lambda max of Oxcarbazepine pure drug was found to be $256 \mathrm{~nm}$. This shows that the drug obtained was in pure form. Further, the absorbance of multiple concentrations of the oxcarbazepine is presented in Table 2 and Figure 1.

IR Spectroscopy: The IR spectrum of the pure drug was similar to that of Oxcarbazepine which indicates that the drug obtained is pure.

\section{Absorbance data for standard calibration of oxcarbazepine}

\section{Solubility analysis}

The solubility of Oxcarbazepine in a buffer solution of $\mathrm{pH} 1.2$ was found to be $0.021 \mathrm{mg} / \mathrm{ml}, 0.0789 \mathrm{mg} / \mathrm{ml}$ in $\mathrm{pH} 6.8$ and and $0.072 \mathrm{mg} / \mathrm{ml}$ in $\mathrm{pH}$ 7.4. The solubility of melt sonocrystallized oxcarbazepine in a buffer solution of $\mathrm{pH} 1.2$ was found to be $0.0712 \mathrm{mg} / \mathrm{ml}, 0.114 \mathrm{mg} / \mathrm{ml}$ in $\mathrm{pH} 6.8$ and $0.085 \mathrm{mg} / \mathrm{ml}$ in $\mathrm{pH}$ 7.4. Results obtained by carrying out saturation solubility studies indicated that both oxcarbazepine and melt sonocrystallized oxcarbazepine had better solubility in $\mathrm{pH} 6.8$ buffer.

\section{X-Ray Powder Diffraction (XRPD)}

The XRPD pattern of both OXC and MSCOXC showed characteristic diffraction peaks which were

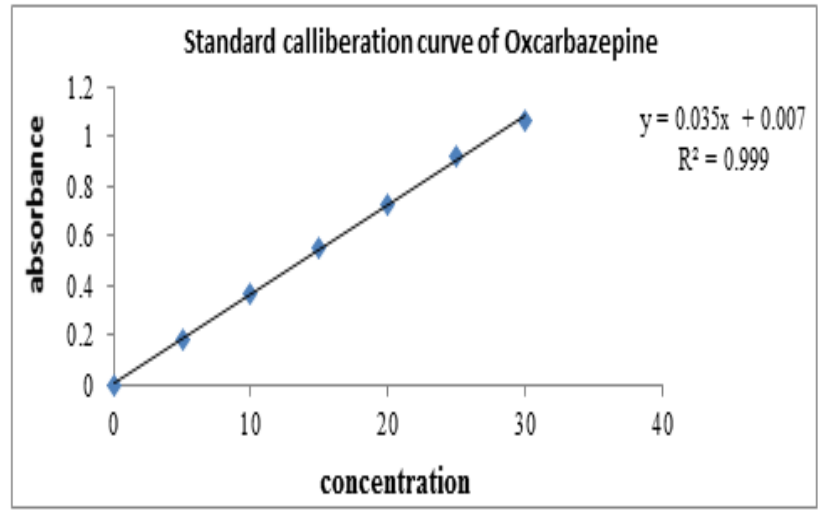

Figure 1: Standard calibration curve of Oxcarbazepine.

\begin{tabular}{|c|c|c|} 
Table 2: Absorbance of multiple concentrations of \\
S. No. & $\begin{array}{c}\text { Concentration }(\boldsymbol{\mu} \mathrm{g} / \\
\mathrm{ml})\end{array}$ & Absorbance \\
\hline 1 & 0 & 0.00 \\
\hline 2 & 5 & 0.188 \\
\hline 3 & 10 & 0.370 \\
\hline 4 & 15 & 0.550 \\
\hline 5 & 20 & 0.727 \\
\hline 6 & 25 & 0.918 \\
\hline 7 & 30 & 1.070 \\
\hline
\end{tabular}

also seen in the MSCOXC indicating no structural changes. The intensity of the peaks of MSCOXC was low as compared to the peaks of OXC indicating the difference in the particle size of the samples; presented in Figures 2 and 3.

\section{Scanning Electron Microscopy (SEM)}

The SEM of the pure Oxcarbazepine particles and MSCOXC particles are shown in Figures 4 and 5 . The crystals of the original form of the drug i.e.

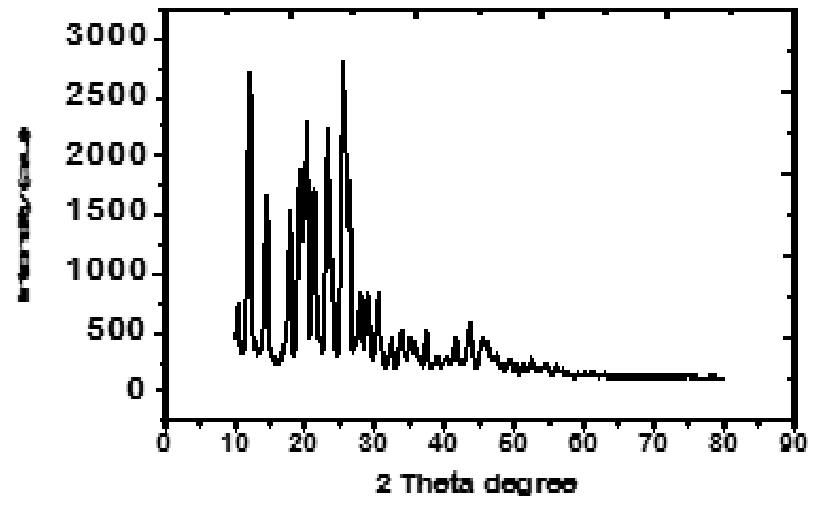

Figure 2: XRPD pattern of Oxcarbazepine (OXC).

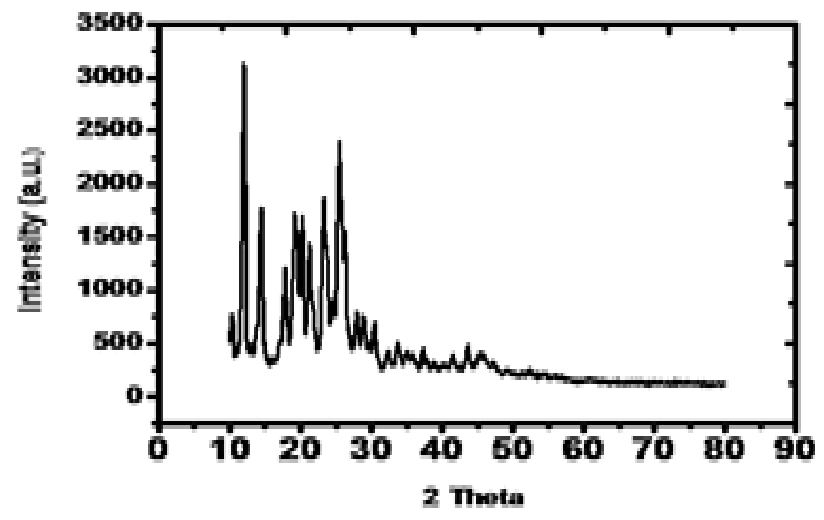

Figure 3: XRPD pattern of Melt sonocrystallized Oxcarbazepine (MSCOXC).

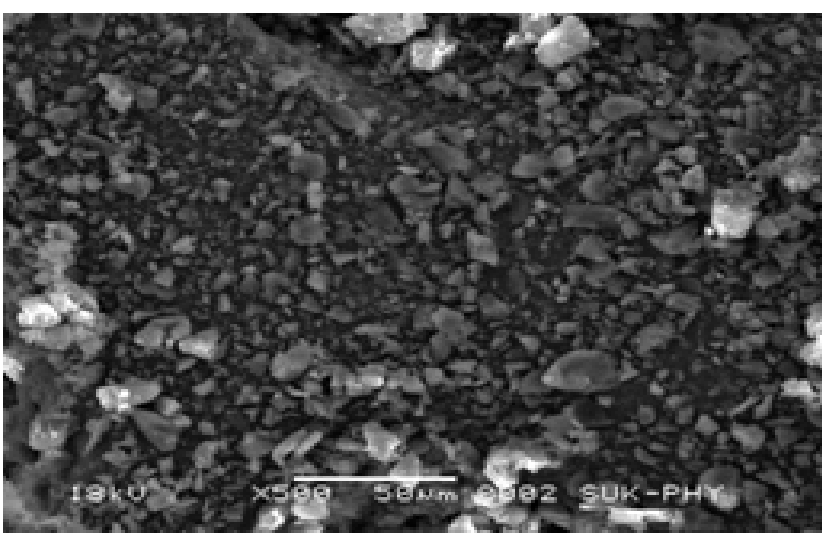

Figure 4: Scanning Electron Microscopy of Oxcarbazepine. 
Oxcarbazepine were large with defined boundaries whereas the MSC form shows smaller particles.

\section{Differential Scanning Calorimetry (DSC)}

The melting point of oxcarbazepine pure drug was found to be in the range of $215-219^{\circ} \mathrm{C}$. DSC peak of oxcarbazepine was found to be $217.74^{\circ} \mathrm{C}$. Similarly, melt-sonocrystallized oxcarbazepine showed a peak of $217.74^{\circ} \mathrm{C}$. This indicates that no modification has occurred during the melt sonocrystallization technique; Figure 6 and 7.

\section{Compatibility studies \\ Differential Scanning Calorimetry (DSC)}

The DSC peak of melt sonocrystallized oxcarbazepine with excipients was seen at $214.99^{\circ} \mathrm{C}$. Peaks obtained indicate that the drug was found to be compatible with the excipients; Figure 8.

\section{Evaluation of Tablets}

\section{Precompression studies}

The angle of repose for powder was found to be in the range of $18^{\circ}-25^{\circ}$. Bulk density was found to be $0.4 \mathrm{~g} /$

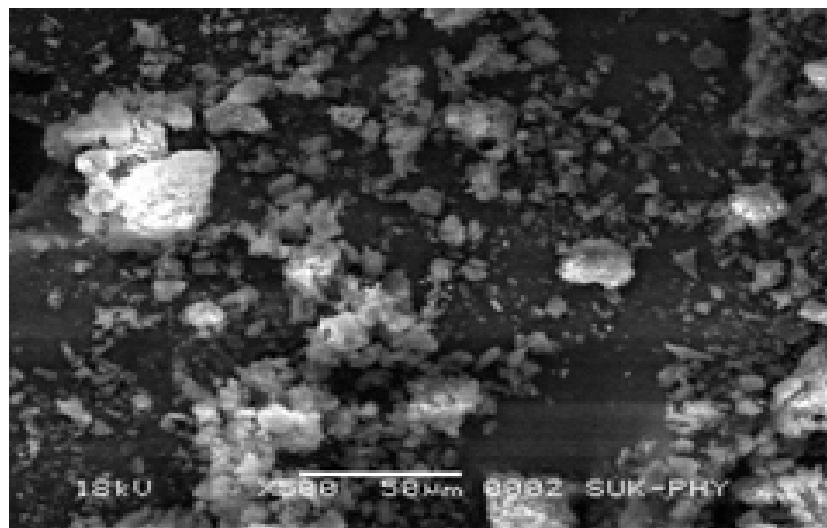

Figure 5: Melt sonocrystallization Oxcarbazepine.

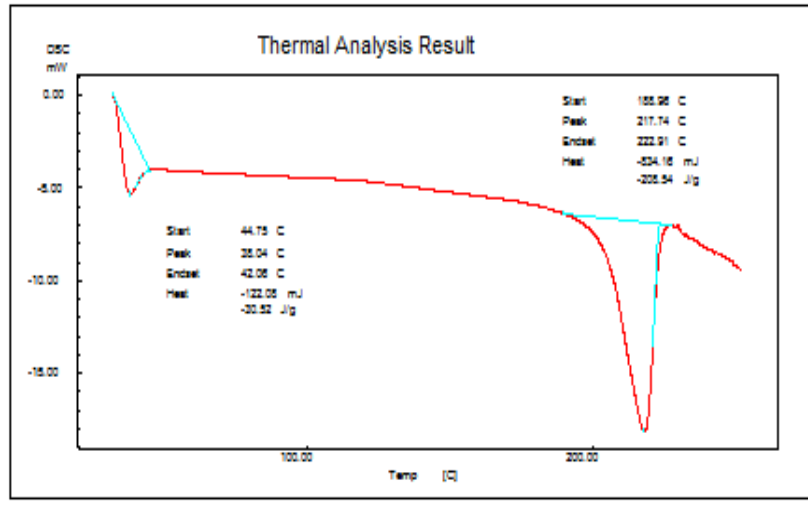

Figure 6: DSC peak of oxcarbazepine pure drug. $\mathrm{ml}-0.39 \mathrm{~g} / \mathrm{ml}$ and tap density was found to be in the range of $0.414 \mathrm{~g} / \mathrm{ml}$ to $0.490 \mathrm{~g} / \mathrm{ml}$. Hausner's ratio was found to be in the range of 1.04-1.22. The percentage compressibility range was found to be $5.70 \%-18.36 \%$. The average weight of tablets prepared was in the range of $200 \pm 0.63 \mathrm{mg}$ to $199 \pm 0.33 \mathrm{mg}$. The hardness of tablets was found to be in the range of $3 \pm 0.02$ to $3 \pm 0.003 \mathrm{~kg} / \mathrm{cm}^{2}$. Thickness was found to be in that range of $4 \pm 0.03$ to $4 \pm 0.05 \mathrm{~mm}$. The diameter was uniform and found to be $8 \mathrm{~mm}$. Friability was below $1 \%$.

\section{Drug content}

Absorbance was measured at $256 \mathrm{~nm}$. The percentage of drug content was found to be in the range of $96.38 \%-98.54 \%$.

\section{In vitro drug release}

This test was performed as triplicates for each batch of the formulation; pure drug and marketed formulation. The results are given in Figures 9-11.

\section{Selection and optimization of mobile phase}

The mobile phase selected was Ethyl acetate: Methanol in the ratio $(8: 2 \mathrm{v} / \mathrm{v})$ as it showed the best

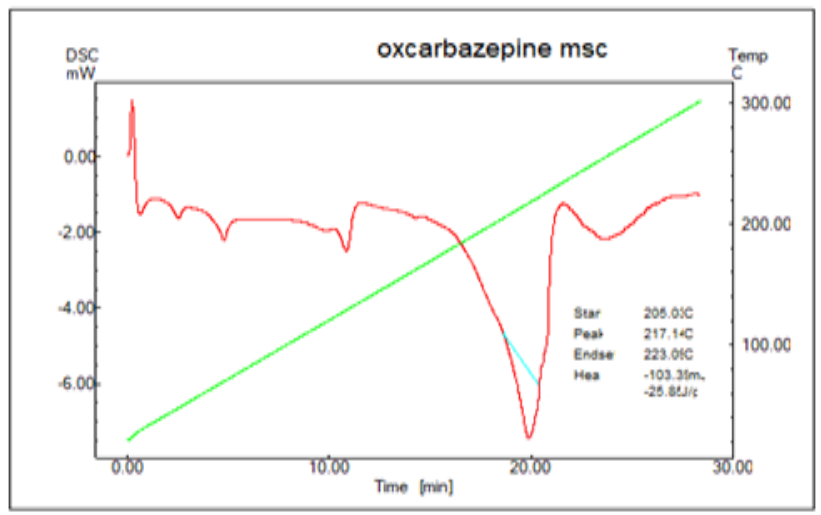

Figure 7: DSC peak of melt-sonocrystallized oxcarbazepine.

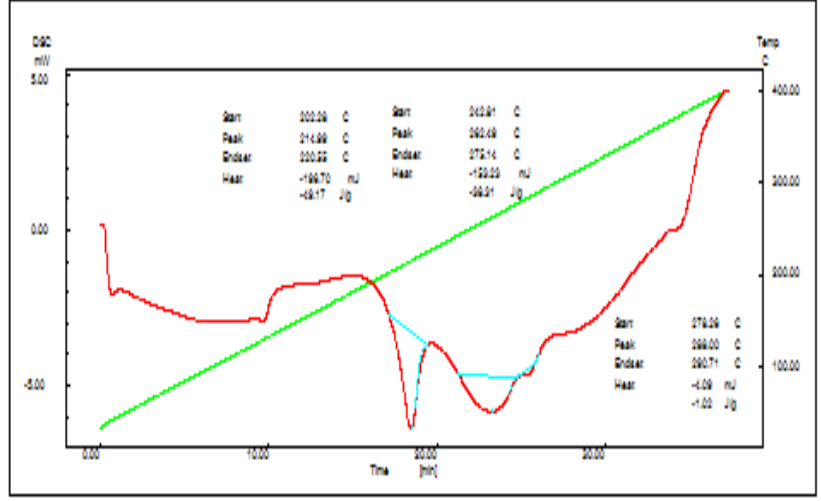

Figure 8: DSC peak of melt-sonocrystallized oxcarbazepine with excipients. 
separation, compact spot s at the $\mathrm{R}_{f} 0.582$. The $\mathrm{R}_{f}$ value was reproducible at room temperature.

\section{The optimization of chromatographic conditions}

To optimize the mobile phase various mixtures of mobile phases and flow rates were previously tested on the standards. The best results were obtained with a mixture of ethyl acetate and methanol $(8: 2 \mathrm{v} / \mathrm{v})$. The

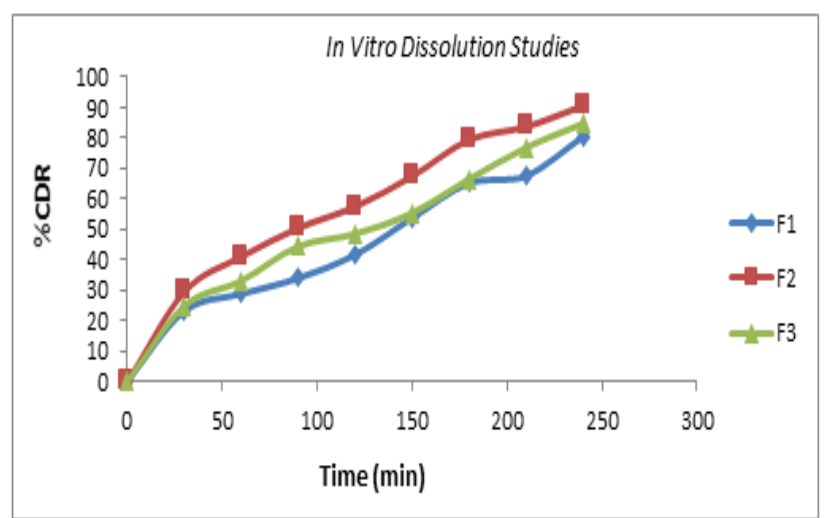

Figure 9: Comparison of the in vitro dissolution release of melt sonocrystallized oxcarbazepine tablets F1, F2, F3 (SSG).

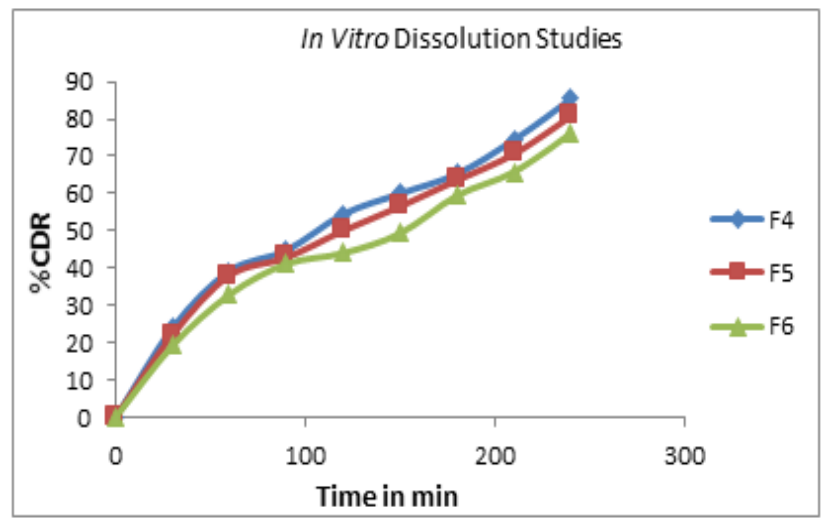

Figure 10: Comparison of the in vitro dissolution release of melt sonocrystallized oxcarbazepine tablets F4, F5, F6 (PGS).

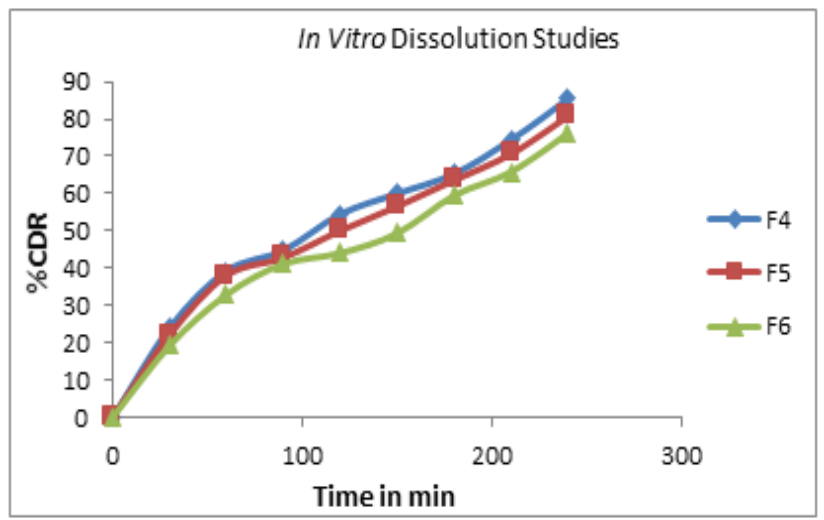

Figure 11: Comparison of the in vitro dissolution release of melt sonocrystallized oxcarbazepine tablet F4, F2 with marketed tablets of oxcarbazepine i.e. Trioptal and Pure drug. densitometry scanner CAMAGTLC SCANNER 4 was used. It was observed that analyses showed the best peak resolution at $259 \mathrm{~nm}$.

\section{Chromatographic Development}

The chromatographic development pattern is shown in Figures 12 and 13 and validation parameters for HPTLC analytical method development and validation are summarized in Table 3 and 4.

\section{Linearity}

Linear regression data showed a good linear relationship over a concentration range of 150 to $350 \mu \mathrm{g} / \mathrm{ml}$ with an equation of $y=9.263 \times 10^{-9} \mathrm{x}+2.668 \times 10^{-3}$ and the correlation coefficient is $\mathrm{R}=99.830 \%$ (Figure 14).

\section{Limit of Detection and Limit of Quantification}

LOD and LOQ were calculated by standard calibration method. LOD for oxcarbazepine was found to be $18 \mu \mathrm{g}$ and LOQ for Oxcarbazepine was found to be $54.8 \mu \mathrm{g}$.

\section{Precision}

Intra-day precision was carried out twice on the same day (replicate of 6 times). An inter-day precision study was carried out on two different days (replicate 6 times).

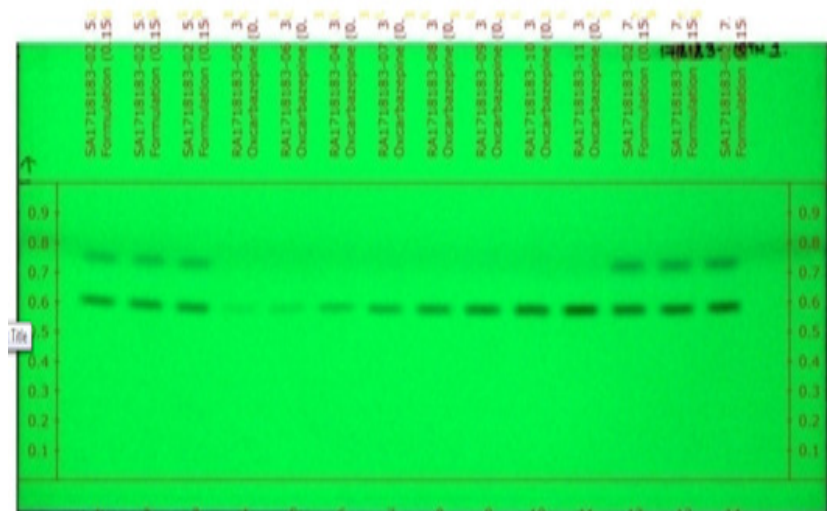

Figure 12: Detection of the developed TLC plate at $254 \mathrm{~nm}$.

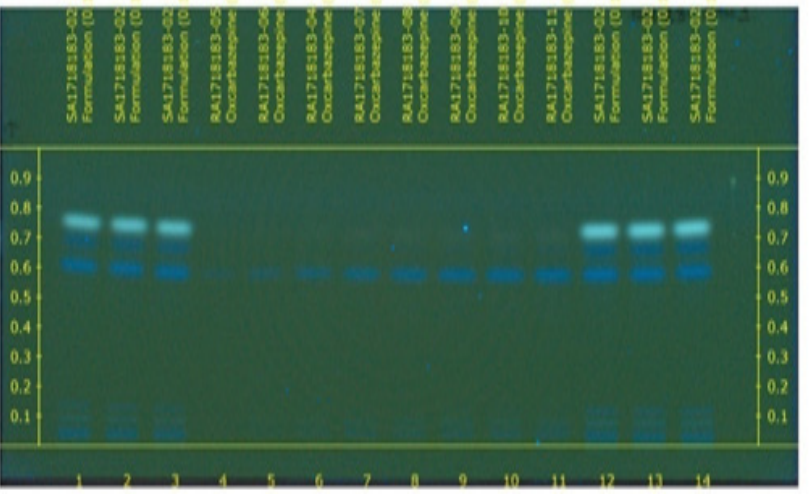

Figure 13: Detection of the developed TLC plate at $366 \mathrm{~nm}$. 
The $\%$ RSD values for intra-day and inter-day precision less than 5\% (Table 4) were considered as an acceptance criterion.

\section{Accuracy}

Accuracy of Oxcarbazepine was carried out in triplicate by comparing the areas of spiking the pure drug of Oxcarbazepine with the formulation (Melt sonocrystallized Oxcarbazepine) at three different levels $(80 \%, 100 \%$ and $120 \%)$ with the area obtained by spiking the formulation with the pure drug. Acceptance criteria; \% recovery should be within the range of $80-115 \%$.

\section{Specificity}

Specificity was carried out by application of the standards, formulation, mobile phase and diluent. The $\mathrm{R}_{f}$ value of Oxcarbazepine the standard was found to be 0.602 . The $\mathrm{R}_{f}$ value of Oxcarbazepine from the formulation was found to be 0.587 , further, the mobile phase and diluents did not show any peaks at the $\mathrm{R}_{f}$ of the standards confirming the method are specific (Figure 15-18).

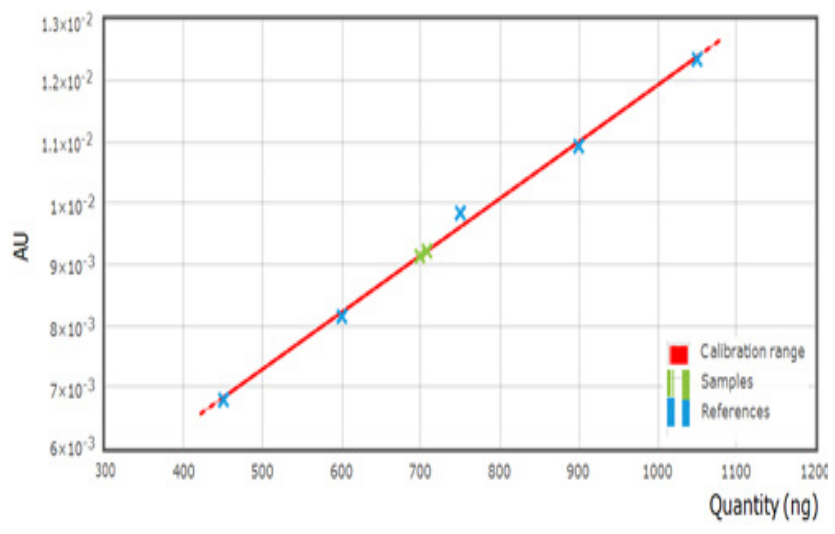

Figure 14: Calibration Curve of Oxcarbazepine by HPTLC.

\begin{tabular}{|c|c|c|c|c|}
\hline & \multicolumn{2}{|l|}{1} & \multicolumn{2}{|l|}{2} \\
\hline $\begin{array}{l}\text { Concentration } \\
(\mu \mathrm{g} / \mathrm{sppot})\end{array}$ & $\begin{array}{l}\text { Mean peak } \\
\text { area }(n=6)\end{array}$ & \% RSD & $\begin{array}{c}\text { Mean peak } \\
\text { area }(n=6)\end{array}$ & $\%$ RSD \\
\hline 100 & 0.0042 & 2.636 & 0.0044 & 2.515 \\
\hline & & & Average & 0.0043 \\
\hline & & & \% RSD & 2.57 \\
\hline
\end{tabular}

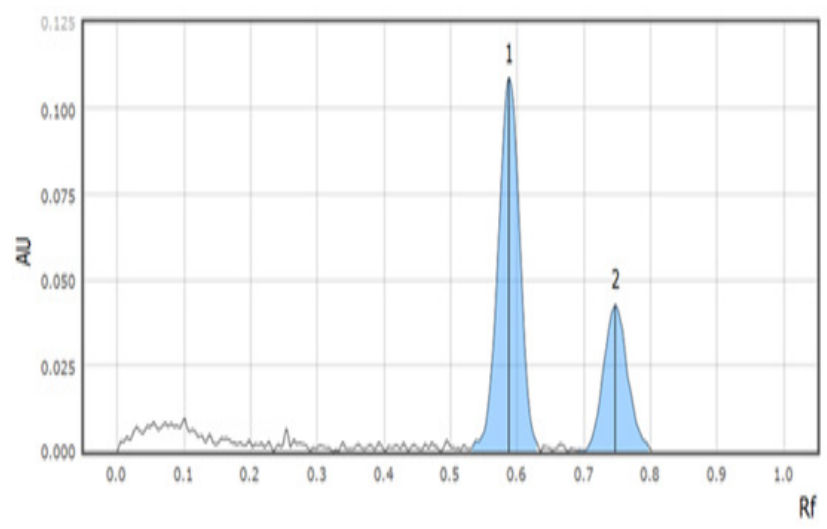

Figure 15: Chromatogram for Specificity of Oxcarbazepine in the formulation.

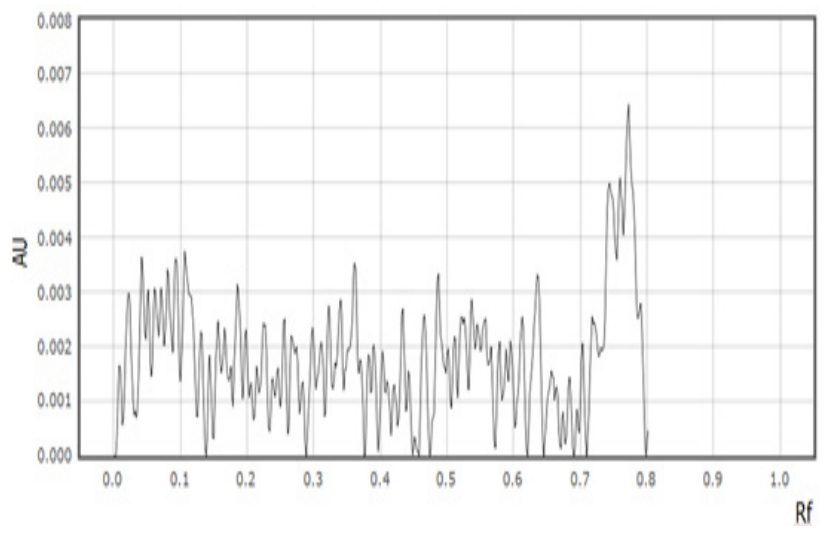

Figure 16: Chromatogram for Specificity of Diluent.

\section{Table 3: HPTLC Analytical Method Development and Validation.}

\begin{tabular}{|c|c|c|c|c|c|c|c|}
\hline \multirow[t]{3}{*}{ Evaluation Parameters } & \multicolumn{7}{|c|}{ Optimized formulation F2 } \\
\hline & \multirow[t]{2}{*}{ Initial day } & \multicolumn{2}{|c|}{$15^{\text {th }}$ day } & \multicolumn{2}{|c|}{$30^{\text {th }}$ day } & \multicolumn{2}{|c|}{$45^{\text {th }}$ day } \\
\hline & & $\mathrm{RT} / 65 \% \mathrm{RH}$ & $\begin{array}{c}40^{\circ} / 75 \% \\
\text { RH }\end{array}$ & $\begin{array}{c}\mathrm{RT} / 65 \% \\
\mathrm{RH}\end{array}$ & $\begin{array}{c}40^{\circ} / 75 \% \\
\text { RH }\end{array}$ & $\mathrm{RT} / 65 \% \mathrm{RH}$ & $\begin{array}{c}40^{\circ} / 75 \% \\
\mathrm{RH}\end{array}$ \\
\hline Disintegration time(sec) & 27.8 & 28.02 & 27.60 & 27.33 & 28.01 & 27.30 & 28.03 \\
\hline Drug content (\%) & $98.54 \%$ & $98.41 \%$ & $98.40 \%$ & $98.36 \%$ & $98.39 \%$ & $98.28 \%$ & $98.12 \%$ \\
\hline$\%$ CDR on the $4^{\text {th }} \mathrm{hr}$ & $90.54 \%$ & $90.53 \%$ & $90.60 \%$ & $90.52 \%$ & $90.02 \%$ & $90.49 \%$ & $90.28 \%$ \\
\hline
\end{tabular}

\begin{tabular}{|c|c|c|c|c|c|}
\hline \multicolumn{5}{|c|}{ Table 4: Validation parameters. } \\
\hline Sample & $\begin{array}{c}\text { Theoretical concentration } \\
\mathrm{mg} / \mathrm{spot}\end{array}$ & $\begin{array}{c}\text { Observed } \\
\text { concentration } \mathrm{mg} / \mathrm{spot}\end{array}$ & $\begin{array}{c}\text { Amount obtained } \\
\mathrm{mg} / \mathrm{tablet}\end{array}$ & $\%$ content & $\%$ RSD \\
\hline Oxcarbazepine & 0.150 & 0.140 & 140 & $93.33 \%$ & $0.89 \%$ \\
\hline
\end{tabular}




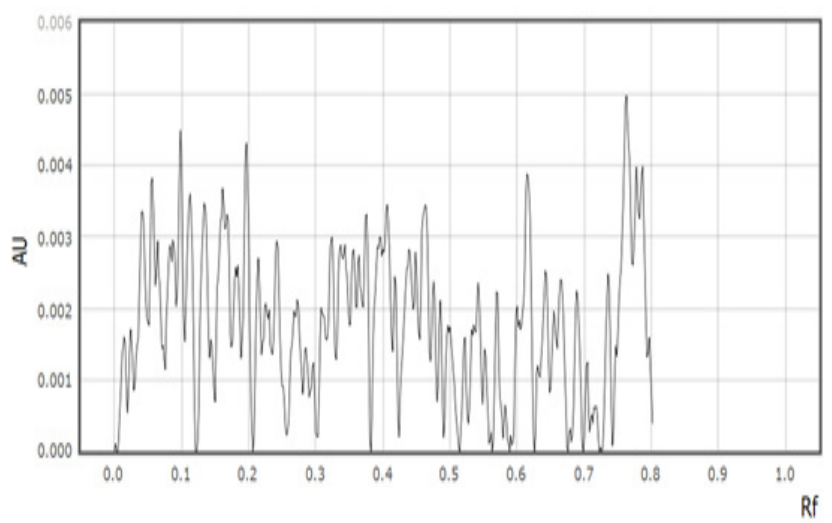

Figure 17: Chromatogram for Specificity of Mobile Phase.

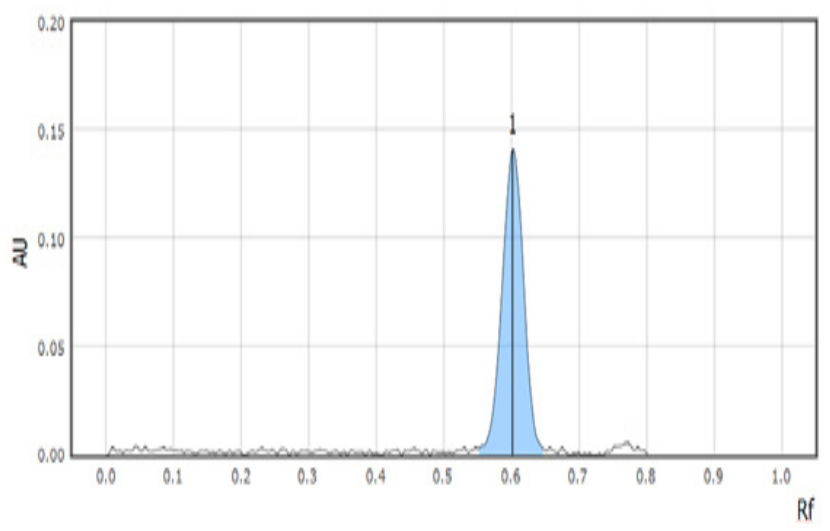

Figure 18: Chromatogram for Specificity of Oxcarbazepine.

\section{CONCLUSION}

The melt sonocrystallization technique enhanced the solubility of the Oxcarbazepine and the saturation solubility revealed it. XRPD, SEM, DSC is the preferred analytical method for the characterization of the MSCOXC. The direct compression method is the preferred method for the formulation of melt sonocrystallized Oxcarbazepine tablets. FTIR and DSC is the preferred analytical method for the compatibility studies. The formulation and post-compression studies were found in the limit. The optimized formulations have a high dissolution profile as compared to the pure drug and marketed formulation and were stable in the 45 days stability studies HPTLC method is developed on the Optimized formulation i.e. F2 melt sonocrystallized Oxcarbazepine for the estimation of the drug in the formulation. The Assay showed $93.3 \%$ of the drug content which was within a limit i.e 90\%-110\% as per I.P. with \% RSD less than $2.00 \%$. The developed method is validated and found to be a linear, precise, accurate and specific method.

\section{ACKNOWLEDGEMENT}

The author would like to thank the Principal of KLE College of Pharmacy, Belagavi and Vergo Pharma Research Laboratories Pvt. Ltd., for providing the gift sample of Oxcarbazepine.

\section{CONFLICT OF INTEREST}

The authors declare that there is no conflict of interest.

\section{ABBREVIATIONS}

DSC: Differential scanning calorimetry; FT-IR: Fourier-transform infrared spectroscopy; HPTLC: High-Performance Thin Layer Chromatography; SEM: Scanning Electron Microscopy; XRPD: X-Ray Powder Diffraction.

\section{REFERENCES}

1. Epilepsy. World Health Organization. Available from: https://www.who.int/ news-room/fact-sheets/detail/epilepsy

2. Fan HC, Lee HS, Chang KP, Lee YY, Lai HC, Hung PL, et al. The Impact of Anti-Epileptic Drugs on Growth and Bone Metabolism. Int J Mol Sci. 2016;17(8):1242.

3. Beig A, Lindley D, Miller JM, Agbaria R, Dahan A. Hydrotropic solubilization of lipophilic drugs for oral delivery: The effects of urea and nicotinamide on carbamazepine solubility-permeability interplay. Front Pharmacol. 2016;7:379.

4. Manish M, Harshal J, Anant P. Melt sonocrystallization of ibuprofen: Effect on crystal properties. Eur J Pharm Sci. 2005;25(1):41-8.

5. Gracin S, Uusi-Penttilä M, Rasmuson ÅC. Influence of ultrasound on the nucleation of polymorphs of p-aminobenzoic acid. Crystal Growth and Design. 2005;5(5):1787-94.

6. Attimarad M, Ahmed KK, Aldhubaib BE, Harsha S. High-performance thin layer chromatography: A powerful analytical technique in pharmaceutical drug discovery. Pharm Methods. 2011;2(2):71-5.

7. Deshmukh V, Deshmukh T, Deshmukh M, Jadhav P. Design and development of melt sonocrystallization technique for carbamazepine. Indian J Pharm Educ. 2013;47(2):199-205. 


\section{SUMMARY}

The present study reveals that the application of the melt sonocrystallization technique to BCS class II drug Oxcarbazepine has resulted in the enhancement of solubility. The study has demonstrated the role of ultrasonic energy in particle size reduction and change in crystal habit. Melt sonocrystallized Oxcarbazepine was prepared from a pure drug of Oxcarbazepine using the sonocrystallization technique where the melt form of the drug is sonocrystallized using probe tip sonicator. The saturation solubility revealed that the solubility of Melt sonocrystallized Oxcarbazepine $(0.114 \mathrm{mg} / \mathrm{ml})$ was higher than the pure Oxcarbazepine $(0.078 \mathrm{mg} / \mathrm{ml})$ in the buffer solution of $\mathrm{pH}$ 6.8. The characterization of the Melt sonocrystallized Oxcarbazepine was done by carrying out XRPD, SEM and DSC analysis. XRPD analysis revealed that the MSCOXC drug was showing low-intensity peaks which indicates that the change in crystal habit has occurred and the particle size has been decreased.SEM analysis revealed that the application of ultrasonic energy has resulted in the formation of a porous surface on the drug particles which contributes to the solubility enhancement.DSC showed no change in the melting point of the MSCOXC indicating no modification on the melting properties of the drug. Preformulation studies were performed to examine the compatibility between the drug melt sonocrystallized Oxcarbazepine and polymers. The IR spectra revealed that functional group peaks of Oxcarbazepine, Melt Sonocrystallized Oxcarbazepine and MSCOXC with excipients were found to be in the given limit and the DSC thermogram showed no change in the melting point of the drug. This indicates that there was no interaction between the polymer and drug and hence they are compatible. Directly compressible tablets of Melt Sonocrystallized Oxcarbazepine were prepared for oral delivery. Tablets prepared were of uniform size and shape. The percentage drug content of all the prepared formulations lied in the range of 95 to $105 \%$ respectively. The disintegration time was less than 15 min which is the limit for the uncoated tablet. The percentage cumulative drug released of formulations prepared was found to be in the range of $90.51 \%-76.11 \%$ at the end of $4 \mathrm{hr}$. The formulation F2 containing $5 \%$ SSG showed a release of $90.51 \%$ and was considered as an optimized formulation based on several parameters such as friability $(0.21 \%)$, disintegration time $(27.8 \mathrm{sec})$ and in vitro dissolution studies. Stability studies were carried out on F2 batch for 45 days as per $\mathrm{ICH}$ guidelines in normal conditions and accelerated conditions. Tablets were found to be stable at the end of the 45th day. Thus, it can be concluded that Melt Sonocrystallized Oxcarbazepine was proven to be a suitable candidate for formulating oral tablets by direct compression method to achieve enhanced solubility and better patient compliance. In the present work, the mobile phase selected was Ethyl acetate: Methanol in the ratio $(8: 2 \mathrm{v} / \mathrm{v})$ with the $\mathrm{R}_{f}$ value 0.582 and the chromatographic conditions was optimized. The amount of Oxcarbazepine present in the formulation was calculated and the \% Drug Content was found to be 93.33\% with $0.89 \%$ RSD. Validation parameters like Linearity, Accuracy, Precision, Assay and Specificity were carried out. Linearity was found over a concentration range of $150-350 \mu \mathrm{g} / \mathrm{ml}$ with an equation of $y=9.263 \times 10$ ${ }^{9} x+2.668 \times 10^{-3}$ and Correlation coefficient $\left(R^{2}\right) 0.998$ for Oxcarbazepine. LOD for Oxcarbazepine was found to be $18 \mu \mathrm{g}$ and LOQ for Oxcarbazepine was found to be $54.8 \mu \mathrm{g}$. Intra-day precision and Inter-day precision were found to be $<5.0 \%$ which confirmed that the method developed for Oxcarbazepine was precise. The mean recovery for Oxcarbazepine was $90.023 \%$. The \% recovery was within the acceptance limits of $80-115 \%$ hence the method was found to be accurate. It was concluded that the developed HPTLC method is simple, rapid, accurate, precise, economical, specific and reproducible for the qualitative and quantitative determination of Oxcarbazepine with good resolution and high sensitivity.

PICTORIAL ABSTRACT

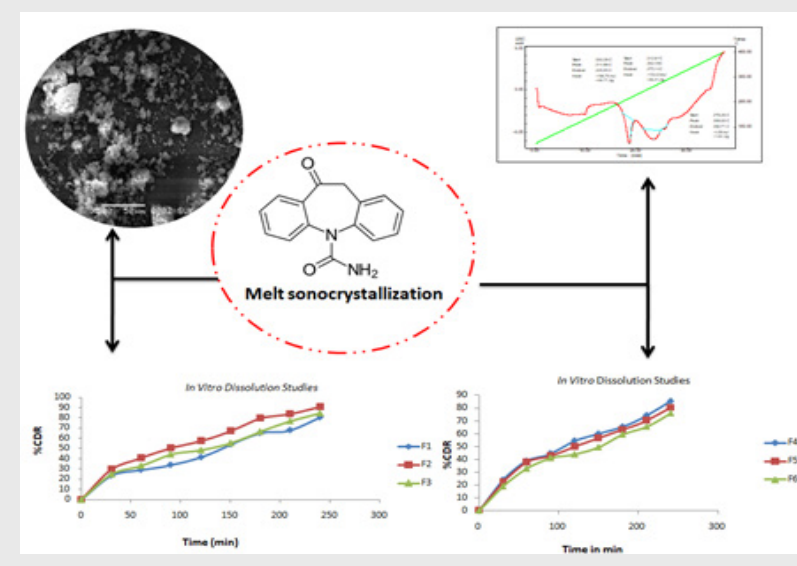

\section{About Authors}

Vinayak Shivamurthi Mastiholimath, is Professor in Department of Quality Assurance at KLE College of Pharmacy, Belagavi, KLE Academy of Higher Education and Research (KAHER), Belagavi-590010

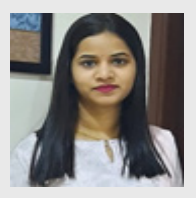

Gauri Pradeep Mashelkar, is a M. Pharm second year student in Department of Quality Assurance at KLE College of Pharmacy, Belagavi, KLE Academy of Higher Education and Research (KAHER), Belagavi-590010.

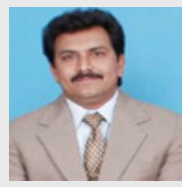

Vinod Kumar Shrishailappa Mannur, is Professor and Head in Department of Quality Assurance at KLE College of Pharmacy, Belagavi, KLE Academy of Higher Education and Research (KAHER), Belagavi-590010. 
Panchaxari Mallappa Dandagi, is Professor in Department of Pharmaceutics at KLE College of Pharmacy, Belagavi, KLE Academy of Higher Education and Research (KAHER), Belagavi-590010.

Pukar Khanal, has been awarded with two times gold medal for his academic performance; currently working as Ph.D Research Scholar at KLE Academy of Higher Education and Research, Belagavi. His area of interest covers gene set enrichment analysis of lead molecule modulated pathway identification, protein-protein network interaction, in silico molecular docking, protein modeling and utilizing Danio rerio as a preliminary animal model. Further, he interests to utilize regression models for the evaluation of PKPD profiles and data correlation with wet lab protocols.

Cite this article: Mastiholimath VS, Mashelkar GP, Mannur VS, Dandagi PM, Khanal P. Solubility Enhancement of Oxcarbazepine by Melt Sonocrystallization Technique to Increase the Bioavailability. Indian J of Pharmaceutical Education and Research. 2021;55(1s):s56-s65. 